\title{
YIELD OF A PORTABLE SAWMILL AND WOOD DRYING OF Hovenia dulcis IN CONVENTIONAL KILN
}

\author{
Pedro Licio Loiola ${ }^{1 *}$, Raquel Marchesan², Morgana Cristina França' ${ }^{1}$, Claudio Gumane Francisco Juízo ${ }^{1}$, Márcio \\ Pereira da Rocha ${ }^{3}$; Ricardo Jorge Klitzke ${ }^{3}$ \\ ${ }^{1}$ Forestry Eng., M.Sc. in Forestry Engineering, PPGEF/UFPR, Curitiba, PR, Brazil - *pedrlicio@hotmail.com; \\ morganaa_franca@hotmail.com; c.gumane@gmail.com \\ ${ }^{2}$ Forestry Eng., Dr., Forest Engineering Course, UFT, Gurupi, TO, Brazil - raquelmarchesan@uft.edu.br \\ ${ }^{3}$ Forestry Eng., Dr., Dept. of Forest Engineering and Technology, UFPR, Curitiba, PR, Brazil - mprocha01@ gmail.com; rklitzke@ufpr.br
}

Received for publication: 18/12/2017-Accepted for publication: 06/03/2018

\begin{abstract}
The objective of this work was to evaluate the yield of sawn wood and the operational efficiency in the sawing of Hovenia dulcis logs in a portable sawmill, as well as to evaluate the behavior of the wood in conventional kiln drying. For this purpose, five trees were selected, from which $14 \operatorname{logs}$ of 1.8 meters in length were obtained to determine the volume, the yield of two diametric classes ( 20 to 24 and 24.1 to $28 \mathrm{~cm}$ ) and the operational efficiency during the sawing of the logs. For the drying process, the parameters of initial temperature, final temperature and drying potential were obtained from the drastic drying method at $100^{\circ} \mathrm{C}$. The yield results showed that there were no statistical differences between the two diametric grades. For operational efficiency, the highest diameter class $\left(1.00 \mathrm{~m}^{3} /\right.$ worker/day) was higher than the lower diameter class $\left(0.70 \mathrm{~m}^{2} /\right.$ worker/day). For the drying of Hovenia dulcis wood, it is possible to consider this species as a difficult drying type according to the parameters found for the elaboration of the drying programs. In addition, the moisture loss of the wood occurred slowly due to its low permeability.

keywords: Portable Sawmill, operational efficiency, drying program.
\end{abstract}

\section{Resumo}

Rendimento de uma serraria portátil e secagem da madeira de Hovenia dulcis em estufa convencional. Este trabalho teve por objetivo avaliar o rendimento em madeira serrada e a eficiência operacional no desdobro da madeira em uma serraria portátil, assim como o comportamento da madeira de Hovenia dulcis na secagem convencional. Para tanto, foram selecionadas 5 árvores, sendo posteriormente escolhidas 14 toras que foram traçadas com 1,8 metros de comprimento, para determinação do volume, rendimento de duas classes diamétricas ( 20 a 24 e 24,1 a $28 \mathrm{~cm}$ ) e a eficiência operacional durante o desdobro das toras. Em relação a secagem, foram obtidos os parâmetros de temperatura inicial, final e potencial de secagem, pelo método de secagem drástica a $100^{\circ} \mathrm{C}$ de pequenas amostras. Os resultados do rendimento demonstraram que não houve diferenças estatísticas entre as duas classes diamétricas. Para a eficiência operacional, a maior classe diamétrica $\left(1,00 \mathrm{~m}^{3} /\right.$ operário/dia) apresentou-se superior a menor classe diamétrica $\left(0,70 \mathrm{~m}^{2} /\right.$ operário/dia). E para a secagem da madeira de Hovenia dulcis, pode-se considerar uma espécie de difícil secagem em função dos parâmetros encontrados para elaboração dos programas de secagem, além disso, a perda de umidade da madeira ocorreu de forma lenta, em função de sua baixa permeabilidade.

Palavras-chave: Serraria móvel, eficiência operacional, programa de secagem.

\section{INTRODUCTION}

Hovenia dulcis Thunberg (grape from Japan) is an arboreous species of great size and natural occurrence in Eastern Asia, mainly in the islands of Japan, China and Korea (CARVALHO, 2004). In south Brazil, it is widespread by the states of Santa Catarina and Rio Grande Do Sul and by the southwest of Paraná. In addition, it is considered an invasive species by environmental agencies due to its easy dispersion and adaptability (SUSIN et al., 2014).

In Brazil, it is not found any commercial reforestation of this species, only dispersed trees with different ages and diameters, spread on several rural properties. However, the species has the potential to supply the needs of small rural enterprises, as well as to generate seasonal income for the producer, mainly by the use of its sawn timber.

Farmers commonly use alternative methods, such as portable sawmills in the mechanical processing of species used in small-scale, since they have commercial advantages making a small forest parcel which could not be exploited, producing timber for its own demand and reducing transportation costs and fixed capital. According to Juizo et al. (2015), the processing of saw logs can be economically unviable in fixed sawmills due 
to capital restrictions or local unavailability. However, even if a methodology that provides the greatest cost/benefit in the mechanical processing of wood were to be used, the best ways of evaluating the deforestation activities are the yield and the operational efficiency (MANHIÇA et al., 2013).

In order to use wood after mechanical processing for the manufacture of products with higher added value, the transformation industry requires a raw material with adequate moisture to manufacture the final product. Usually the desired moisture is below the equilibrium humidity of the environment, making the drying in conventional kiln one of the most used processes. This process allows greater versatility and flexibility in the control of the variables involved, but, on the other hand, it has high costs.

Despite this, there is little information on the drying behavior of Hovenia dulcis. Only Vivian et al. (2010) analyzed the influence of pre-treatments on the drying rate at two temperatures $\left(60\right.$ and $\left.90^{\circ} \mathrm{C}\right)$ in small samples and Susin et al. (2014) had studied the drying of the wood of Grape from Japan in two methods of drying (natural and in solar kiln).

Given the above, this study aimed to evaluate the yield of lumber and operational efficiency in sawing timber into a portable sawmill as well as the behavior of wood Hovenia dulcis in conventional drying.

\section{MATERIAL AND METHODS}

The trees used in this research were obtained from the Mixed Ombrophylous Forest, located in the Southwest region of the Paraná state. In order to determine the yield and the operational efficiency, through the cutting, five trees selectively chosen depending on the needs of specimens with straight shank, in perfect state of sanity and by means of the cutting and subsequent drying of the wood of Hovenia dulcis, representing the species at random.

The trees had an average age of 18 years, average diameter at breast height (DBH) of $24.9 \mathrm{~cm}$ and average height of the commercial shaft of 7.2 meters. 14 logs were selected from five trees, which were divided into two diametric classes: class 1 from 20.0 to $24.0 \mathrm{~cm}$, and class 2 from 24.1 to $28.0 \mathrm{~cm}$, both with $1.80 \mathrm{~m}$ of length. To determine the volume of the logs, the Smalian method was adopted, according to Equation 1.

$V=\frac{(\mathrm{g} 1+\mathrm{g} 2)}{2} \times \mathrm{L}$

In which: $\mathrm{V}$ : volume of $\operatorname{logs}\left(\mathrm{m}^{3}\right)$; $\mathrm{g} 1$ : sectional area of the inferior extremity of the $\log \left(\mathrm{m}^{2}\right)$; $\mathrm{g} 1$ : sectional area of the superior extremity of the $\log \left(\mathrm{m}^{2}\right)$; e L: length of the $\log$.

\section{Cutting of logs}

All the $\log$ s were sawn in a portable saw provided with simple horizontal ribbon with thickness of $1,1 \mathrm{~mm}$ and cutting edge of $2,3 \mathrm{~mm}$, having the engine $13 \mathrm{HP}$ of normal rated power. Final thickness of the parts was defined in $2,5 \mathrm{~cm}$ and changeable width, with a tangential cutting system being used. In the cutting, blocks were obtained with the withdrawal of the four wood pieces, and then sequential cuts were performed, as shown in Figure 1.

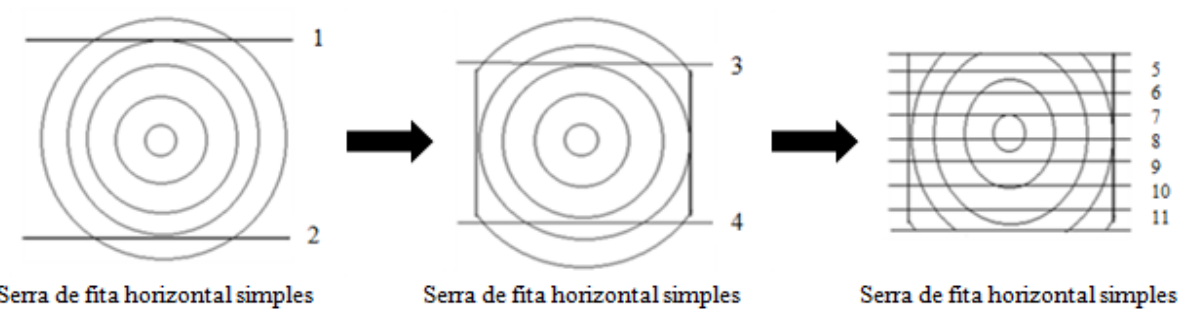

Figure 1. Cutting model used for the processing of Hovenia dulcis logs.

Figura 1. Modelo de desdobro utilizado para o processamento de toras de Hovenia dulcis

Yield in sawn wood and operational efficiency

In order to determine the income in green sawed wood, the widths, thicknesses and lengths of the boards for the determination of individual volume of the green sawed wood were obtained. After the volume of each sawed wooden part was calculated, it was obtained the total volume in green wood sawed by the sum of the individual volume of the boards $\left(\mathrm{m}^{3}\right)$. Thus, it was proceeded the determination from the income in percentage, for the reason of the sum of the board volumes $\left(\mathrm{m}^{3}\right)$ and of the logs total volume $\left(\mathrm{m}^{3}\right)$ that originated the boards. 
For determination of the operational efficiency, it was performed the cutting of the logs, being timed the period since the shipment of each log in portable saw until the end of its cutting. The time was recorded for each $\log$ and used for the calculation of operational efficiency (equation 2).

$\mathrm{E}=\frac{480 * \mathrm{~T}}{\mathrm{t} * \mathrm{O}}$

In which: E: technical efficiency in $\mathrm{m}^{3}$ per worker per shift; 480 minutes: 8 hour shift; $\mathrm{T}$ : $\log$ volume in sawn $\mathrm{m}^{3}$; $\mathrm{t}$ : time in minutes of the sawing of the log; and $\mathrm{O}$ : the number of workers who work in the mill.

\section{Determination of basic specific density and apparent wood}

The assays for the determination of the basic and apparent specific mass at $12 \%$ of the Hovenia dulcis were carried through according to the recommendations of the American Society for Testing and Materials, ASTM D-2395 (ASTM, 2005), being sampled 20 test bodies.

\section{Elaboration of the drying program}

For the elaboration of the drying program, five boards were used. Random parts were sampled taking in consideration its phytosanitary aspect. For each board, five test specimens with the dimensions of $50 \mathrm{x} 10 \mathrm{x}$ $150 \mathrm{~mm}$ (width $\mathrm{x}$ thickness $\mathrm{x}$ length) were made, totaling 25 specimens to be chosen for the accelerated drying program elaboration, called drastic drying at $100^{\circ} \mathrm{C}$, based on the procedures described by Klitzke and Batista (2010), Eleotério et al. (2014) and Eleotério et al. (2015).

In such methodology, the parameters of the initial temperature of dry bulb, final temperature of dry bulb and potential of drying are determined. The method of drastic drying is based on the principle that small samples, when displayed to the effect of the thermal radiations in stove at $100^{\circ} \mathrm{C}$ and without forced ventilation, provide similar behavior of the drying in conventional chambers. After that, its content of initial moisture for the gravimetrical method was determined, as recommendations of ASTM D-4442 (2005).

\section{Variables used for the elaboration of the program of drastic drying at $100^{\circ} \mathrm{C}$ \\ Calculation of the drying speed}

For the calculation of the drying speed, the methodology of Terazawa (1965) was used as theoretical and methodological base. The samples had been weighed in digital balance with a precision of $0,01 \mathrm{~g}$ for determination of the initial mass. With the aid of digital caliper $(0.01 \mathrm{~mm})$, its dimensions of width, thickness and length were taken, being performed measurements periodically each 1 hour, during the first 12 hours of the assay. After this period, the measurements had been carried through each 2 hours until the ending of the assay.

The calculation of drying speed was determined from the green condition of wood up to $30 \%$ of moisture (capillary rate), from green until 5\% of moisture (capillary and hygroscopic rate), and from 30 to $5 \%$ moisture (hygroscopic rate). For this, Equations 3, 4 and 5 were used.

$V 1=\frac{\mathrm{Mv}-\mathrm{M} 30 \%}{\mathrm{~T} 1 * \text { área }}$

In which: V1: speed of drying of the green condition up to $30 \%$ of moisture [g. $\left({ }^{\mathrm{cm}} 2\right.$.hour) - 1]; Mv: Green mass (g); M30\%: mass at 30\% of moisture (g); and T1: drying time of the green condition up to 30\% (hours).

$V 2=\frac{\mathrm{Mv}-\mathrm{M} 5 \%}{\mathrm{~T} 2 * \text { rea }}$

In which: V2: drying speed of the green condition up to 5\% of moisture [g. $\left(\mathrm{cm}^{2}\right.$.hour) - 1]; M5\%: Green mass (g) at 5\%; M30\%: mass at 30\% of moisture (g); and T1: drying time of the green condition up to 5\% of moisture (hours).

$V 3=\frac{\mathrm{M} 30 \%-\mathrm{M} 5 \%}{\mathrm{~T} 3 * \text { área }}$

In which: V3: drying speed of the green condition of 30 up to 5\% of moisture [g. $\left(\mathrm{cm}^{2}\right.$.hour) - 1]; M30\%: mass (g) at $30 \%$ of moisture ; M5\%: mass at $5 \%$ of moisture $(\mathrm{g})$; and T3: drying time of 30 up to 5\% of moisture (hours). 


\section{Water in wood}

The water percentage in the wood was calculated using the humid mass, dry mass and percentile of water of the wood. First, it was calculated water mass for the green wood, 30\% and 5\% of moisture (in grams). In the green wood, the value was obtained by the subtraction of the sample. The masses at $30 \%$ and $5 \%$ were obtained by means of weight estimation in the respective moistures by Equations 6, 7 and 8 .

$\mathrm{E}_{30 \%}=\frac{130}{100} * \mathrm{~ms}$

In which: $\mathrm{E}_{30 \%}$ :estimate of weight $30 \%$; ms: dry mass (g).

$\mathrm{E}_{5 \%}=\frac{105}{100} * \mathrm{~ms}$

In which: estimate of weight $5 \%$; ms: dry mass $(\mathrm{g})$.

$\mathrm{A}=\frac{\mathrm{ma}}{\mathrm{mu}} * 100$

In which: A: water percentage in the wood (\%); ma: water mass in the green wood, at $30 \%$ and $5 \%$ of moisture; e mu: humid mass of the wood $(\mathrm{g})$.

\section{Parameters for elaboration of the program}

The variables related to the assays for the elaboration of the program of drastic drying (Table 1) were applied in the equations presented in Table 2, defining the main parameters of the drying programs, as the initial temperature (TI), the final temperature (TF) and the potential of drying (PS). Equations 3, 4 and 5 assisted in the calculations of the drying speed for each phase of wood moisture removal that was used to determine the drying parameters (Table 2).

Table 1. Variables related to the accelerated drying speed test.

Tabela 1. Variáveis relacionadas ao ensaio da velocidade de secagem acelerada.

\begin{tabular}{|c|c|c|c|}
\hline Variable & Description & moisture & Unit \\
\hline $\mathrm{Ui}$ & Initial moisture & Green & $\%$ \\
\hline $\mathrm{T} 1$ & Drying time & Green at $30 \%$ & Hour \\
\hline $\mathrm{T} 2$ & Drying time & 30 at $5 \%$ & Hour \\
\hline T3 & Drying time & Green at $5 \%$ & Hour \\
\hline V1 & Speed of drying & Green at $30 \%$ & g. $\left(\mathrm{cm}^{2}\right.$.hour $)-1$ \\
\hline $\mathrm{V} 2$ & Speed of drying & 30 at $5 \%$ & g. $\left(\mathrm{cm}^{2}\right.$ hour $)-1$ \\
\hline V3 & Speed of drying & Green at $5 \%$ & g. $\left(\mathrm{cm}^{2}\right.$.hour $)-1$ \\
\hline $\mathrm{R} 1$ & Top crack & Green at $30 \%$ & adimensional \\
\hline $\mathrm{R} 2$ & Top crack & 30 at $5 \%$ & adimensional \\
\hline R3 & Top crack & Green at $5 \%$ & adimensional \\
\hline
\end{tabular}

Table 2 Equations to determine the parameters of the conventional drying of Hovenia dulcis wood.

Tabela 2. Equações para determinar os parâmetros da secagem convencional da madeira de Hovenia dulcis.

\begin{tabular}{ccccc}
\hline Parameter & \multicolumn{4}{c}{ Equation } \\
\hline TI[IT] & $27,9049+$ & $0,7881 * \mathrm{~T} 2+$ & $419,0254 \mathrm{~V} 1+$ & $1,9483 * \mathrm{R} 2$ \\
TF & $49,2292+$ & $1,1834 * \mathrm{~T} 2+$ & $273,8685 \mathrm{~V} 2+$ & $1,0754 * \mathrm{R} 1$ \\
PS & $1,4586-$ & $30,4418 * \mathrm{~V} 3+$ & $42,9653 * \mathrm{~V} 1+$ & $0,1424 * \mathrm{R} 3$ \\
\hline
\end{tabular}

\section{Drying in conventional greenhouse of laboratory}

For validation of the drying program elaborated for the method of drastic drying at $100^{\circ} \mathrm{C}$, it was performed the drying in a pilot conventional kiln with capacity of $1 \mathrm{~m}^{3}$ of sawed wood. In this process, 66 boards of Hovenia dulcis were used in each load, in the nominal dimensions of $25 \mathrm{~mm}$ of thickness and $70 \mathrm{~cm}$ of length, being kept the original width of the board. The air speed was kept constant in 2,5m/min, according to recommendation of Hildbrand (1970). 
Two drying loads were performed. In one load, the potential of drying in function of elaborated program was maintained, in the other load, an increased potential of drying, aiming to verify the behavior of the wood regarding the speed of drying and quality of the parts. For both the drying loads (soft drying and drastic drying), the stage of heating the wood was performed for a period of six hours and the finishing of the drying having comprehending the stage of standardization (4 hours) and conditioning of the wood (6 hours).

\section{Data analysis}

For the lumber yield study and operational efficiency, it was a completely randomized design (DIC), in which tests of normality (Shapiro-Wilk) and homogeneity (Bartlett) were carried out. Then it was applied the analysis of variance and, when the null hypothesis (H0) was rejected, the Tukey test was used for the comparison of averages. For the study of wood drying, when it was verified the need for regression analysis to relate the variables involved, this was used for the selection of model that performed best fit $\left(\mathrm{R}^{2}\right)$.

\section{RESULTS}

\section{Yield in sawed wood and operational efficiency}

In Table 3, the incomes in wood sawed green found for the wood of Hovenia dulcis in portable saw consist of $47,30 \%$ and $48,94 \%$ for diametric classes 1 and 2, respectively. It can be observed that it did not have statistic differences to the level of $5 \%$ of probability, due to proximity of the diameters between the classes and also to the homogeneous quality of logs. For the operational efficiency, there are significant differences to the level of $5 \%$ probability of error for classes 1 and 2, being the biggest class the one that obtained greater operational efficiency $\left(0,95 \mathrm{~m}^{3} /\right.$ labour/shift) (Table 3$)$. This result was the expected due to the increase on the wooden volume in relation to the diameters.

Table 3. Yield in lumber and operational efficiency of Hovenia dulcis cutting in portable sawmill.

Tabela 3. Rendimento em madeira serrada e eficiência operacional no desdobro de Hovenia dulcis em serraria portátil.

\begin{tabular}{ccc}
\hline Diametric Class $(\mathbf{m m})$ & $\begin{array}{c}\text { Yield } \\
(\mathbf{\%})\end{array}$ & $\begin{array}{c}\text { operational Efficiency } \\
(\mathbf{m} \text { //labour/shift })\end{array}$ \\
\hline $1(20-24)$ & 47,30 a $(7,42)$ & 0,72 b $(0,17)$ \\
$2(24,1-28)$ & 48,94 a $(8,06)$ & 0,95 a $(0,20)$ \\
\hline General average & 48,12 & 0,85 \\
\hline F & $0,39^{\text {ns }}$ & $5,3^{*}$ \\
\hline $\begin{array}{l}\text { Values between parentheses correspond to the shunting line standard. }{ }^{*} \text { significant to the level of } 5 \% \text { probability. }{ }^{\text {ns }} \text { not significant to the level } \\
\text { of 5\% probability. F: variation source. }\end{array}$
\end{tabular}

\section{Elaboration of the drying program}

It is observed that the wood of Hovenia dulcis presented basic specific mass of $0,532 \mathrm{~g} . \mathrm{cm}^{-3}$ and apparent specific mass at $12 \%$ of $0,655 \mathrm{~g} . \mathrm{cm}^{-3}$, being able to be classified as moderately weighed wood (Table 4).

Beyond the specific mass, another important factor for the wood drying is the water percentage in the wood (\%). The results presented in Table 4 for the correlation water-wood in the drying programs are important for the prediction of the amount of water that will be removed in the process of conventional drying. This is a support for taking of decisions for the sector of operational planning in regard to the amount and costs related to the thermal and electric energy for the wooden drying. One notices that the wood possess a total water percentage (hair and hygroscopic) of $36,217 \%$ of its total weight, while the hygroscopic water percentage is of $19,175 \%$, being the ratio of water in the cellular structures of the wood to a text of $5 \%$ of moisture $0,038 \%$ of its all up weight.

In addition to the water-wood relationship, other variables, such as time and drying speed, are of the utmost importance in the development of programs for the control and removal of water during the drying process, as it can be seen in table 4 .

Table 4. Physical properties, initial moisture, specific mass and water-wood ratio in Hovenia dulcis wood.

Tabela 4. Propriedades físicas, umidade inicial, massa específica e relação água-madeira na madeira de Hovenia dulcis. 


\begin{tabular}{|c|c|c|c|c|c|c|}
\hline \multirow{2}{*}{$\begin{array}{l}\text { Physical } \\
\text { Properties of } \\
\text { wood }\end{array}$} & \multirow{2}{*}{$\begin{array}{c}\text { Initial } \\
\text { moisture }(\%)\end{array}$} & \multicolumn{2}{|c|}{$\begin{array}{c}\begin{array}{c}\text { specific Mass } \\
\left(\text { g.cm }^{-3}\right)\end{array} \\
\end{array}$} & \multicolumn{3}{|c|}{$\begin{array}{c}\text { Water percentage in the wood } \\
(\%)\end{array}$} \\
\hline & & Basic & $12 \%$ apparent & $\begin{array}{c}\mathrm{M}_{1} \\
\text { (Green) }\end{array}$ & $\begin{array}{c}\mathrm{M}_{2} \\
(\mathrm{U}=30 \%)\end{array}$ & $\begin{array}{c}\mathrm{M}_{3} \\
(\mathrm{U}=5 \%)\end{array}$ \\
\hline Hovenia dulcis & 57,51 & 0,532 & 0,655 & 36,217 & 19,175 & 0,038 \\
\hline DP & 11,88 & 0,040 & 0,055 & 4,36 & 2,48 & 0,01 \\
\hline \multirow{2}{*}{$\begin{array}{l}\text { Water-wood } \\
\text { relationship }\end{array}$} & \multicolumn{3}{|c|}{$\begin{array}{l}\text { Drying time } \\
\text { (hours) }\end{array}$} & \multicolumn{3}{|c|}{$\begin{array}{l}\text { Speed of drying } \\
{\left[\text { g. }\left(. h o u r \mathrm{~cm}^{2}\right)^{-1}\right]}\end{array}$} \\
\hline & $\begin{array}{l}\text { green up to } \\
30 \%\end{array}$ & $\begin{array}{l}30 \% \text { up } \\
\text { to } 5 \%\end{array}$ & green up to $5 \%$ & $\begin{array}{l}\text { green up } \\
\text { to } 30 \%\end{array}$ & $\begin{array}{l}30 \% \text { up to } \\
5 \%\end{array}$ & $\begin{array}{c}\text { green up to } \\
5 \%\end{array}$ \\
\hline Hovenia dulcis & 1,90 & 5,20 & 7,10 & 0,0385 & 0,0125 & 0,0193 \\
\hline DP & 0,84 & 0,95 & 1,37 & 0,0037 & 0,0015 & 0,0019 \\
\hline
\end{tabular}

$\mathrm{M}_{1}$ : percentage (\%) of total water in the wood; $\mathrm{M}_{2}$ : percentage (\%) of water in the wood with $30 \%$ of humidity; $\mathrm{M}_{3}$ : percentage (\%) of water in the wood with $5 \%$ of humidity; DP: standard shunting line; e CV: variation coefficient.

In Figure 1, it is observed the loss of moisture related to the setting time of the H. dulcis wood and the rate of wood drying of $\mathrm{H}$. dulcis in each kinetic phase of drying. The regression model that was better adjusted to the studied species was of [exp (b - bo*tempo]. In this model, a value of coefficient of determination was adjusted $(88.06 \%)$ significant to the level of $1 \%$ and with standard error of the estimate of $1,3429 \%$.
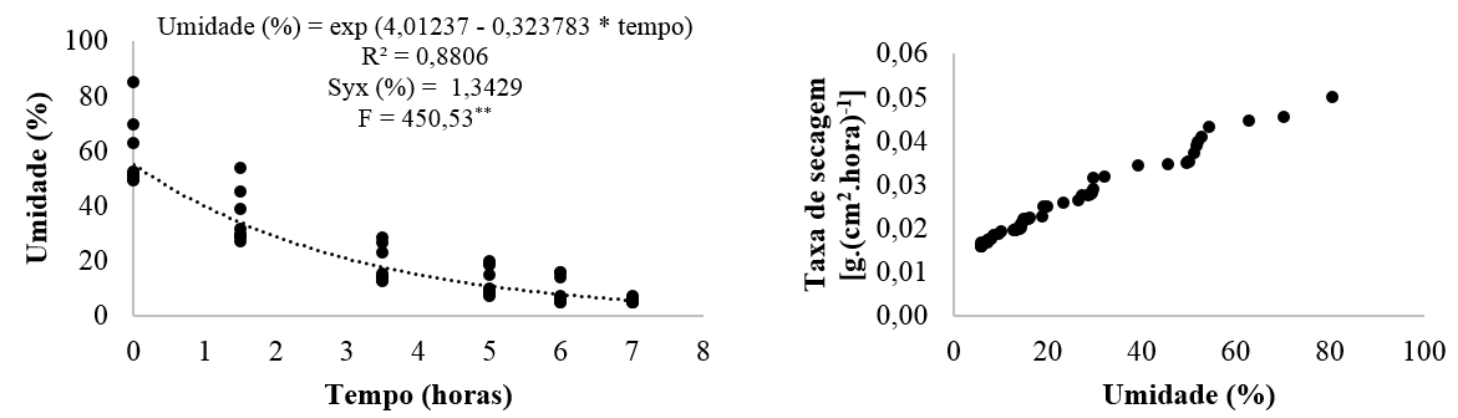

exp: exponential; $\mathrm{R}^{2}$ aj: adjusted coefficient of determination; Syx: standard error of the estimate; F: significance factor; ${ }^{* *}$ level of $1 \%$ of significance.

Figure 2. Regression relating the loss of moisture to the drying time for the H. dulcis wood in the drastic drying at $100^{\circ} \mathrm{C}$ and the drying rate of the Hovenia dulcis wood in each kinetic phase for the drastic drying at $100^{\circ} \mathrm{C}$.

Figura 2. Regressão relacionando a perda de umidade ao tempo de secagem para a madeira de $H$. dulcis na secagem drástica a $100^{\circ} \mathrm{C}$ e taxa de secagem da madeira de Hovenia dulcis em cada fase cinética para a secagem drástica a $100^{\circ} \mathrm{C}$.

The parameters of initial temperature, final temperature and drying potential (Table 5) are similar to those occurred in refractory hardwoods, which use mild temperatures and softer drying potential. The drying potential was of 1,91 , being also able to be related to the anistropic factor of the wood. For woods that have high anisotropy coefficients (2.5), it is recommended the use of low drying potentials (close to 2.0).

Table 5. Parameters of initial, final and potential temperature of drying for the Hovenia dulcis wood for the drastic drying at $100^{\circ} \mathrm{C}$.

Tabela 5. Parâmetros de temperatura inicial, temperatura final e potencial de secagem para a madeira de Hovenia dulcis para a secagem drástica a $100^{\circ} \mathrm{C}$.

\begin{tabular}{cccc}
\hline Hovenia dulcis & $\begin{array}{c}\text { Initial temperature } \\
\left({ }^{\mathbf{0}} \mathbf{C}\right)\end{array}$ & $\begin{array}{c}\text { Final temperature } \\
\left({ }^{\circ} \mathbf{C}\right)\end{array}$ & Potential of drying \\
\hline Average & 37,61 & 62,02 & 1,91 \\
DP & 1,39 & 1,46 & 0,09 \\
\hline
\end{tabular}

DP: standard shunting line CV: variation coefficient. 


\section{Application of the drying program elaborated in the conventional drying}

The definitive potential of drying $(1,91)$ emphasizes the difficulty of water removal of the wood during the drying process. The stages, which purpose is to guarantee the quality of the dry wood (standardization and conditioning), were carried through according to the recommendations of Galvão and Jankowsky (1985) and Simpson (1991). The standardization of wood occurred for a period of 4 hours and the relief of the tensions of drying (conditioning) for a period of 6 hours, always keeping the balanced moisture of the drying environment equal to the desired final moisture for the dry wood. For the accelerated drying program, it is noted that only the drying potential used was high (2.80), and the other stages remained similar to the first program developed (Table 6).

Table 6. Drying programs applied to Hovenia dulcis wood.

Tabela 6. Programas de secagem aplicados à madeira de Hovenia dulcis.

\begin{tabular}{|c|c|c|c|c|}
\hline \multirow[t]{2}{*}{ Soft Drying program } & \multirow{2}{*}{$\begin{array}{c}\text { Initial } \\
\text { Temperature }\left({ }^{\circ} \mathbf{C}\right)\end{array}$} & \multirow{2}{*}{$\begin{array}{c}\begin{array}{c}\text { final Temperature } \\
\left({ }^{\circ} \mathbf{C}\right)\end{array} \\
62 \\
\end{array}$} & \multicolumn{2}{|c|}{$\begin{array}{c}\text { Potential of } \\
\text { drying }\end{array}$} \\
\hline & & & \multicolumn{2}{|c|}{1,91} \\
\hline Completion of drying & $\begin{array}{c}\text { Temperature } \\
\left({ }^{\circ} \mathrm{C}\right)\end{array}$ & moisture balance (\%) & $\begin{array}{l}\begin{array}{l}\text { Time } \\
\text { (hours) }\end{array} \\
\end{array}$ & $\begin{array}{c}\text { Potential of } \\
\text { drying }\end{array}$ \\
\hline Standardization & 62 & (7) & (4) & 1,0 \\
\hline Conditioning & 62 & (9) & (6) & 1,0 \\
\hline Cooling & 45 & (9) & (4) & - \\
\hline \multirow{2}{*}{$\begin{array}{c}\text { Speed up Program of } \\
\text { drying }\end{array}$} & $\begin{array}{c}\text { Initial } \\
\text { Temperature }\left({ }^{\circ} \mathbf{C}\right) \\
\end{array}$ & $\begin{array}{c}\text { final Temperature } \\
\left({ }^{\circ} \mathrm{C}\right)\end{array}$ & \multicolumn{2}{|c|}{$\begin{array}{c}\text { Potential of } \\
\text { drying }\end{array}$} \\
\hline & 40 & 62 & \multicolumn{2}{|c|}{2,8} \\
\hline Completion of drying & $\begin{array}{c}\text { Temperature } \\
\left({ }^{\circ} \mathrm{C}\right)\end{array}$ & moisture balance (\%) & $\begin{array}{l}\text { Time } \\
\text { (hours) }\end{array}$ & $\begin{array}{c}\text { Potential of } \\
\text { drying }\end{array}$ \\
\hline Standardization & 62 & (7) & (4) & 1,0 \\
\hline Conditioning & 62 & (9) & (6) & 1,0 \\
\hline Cooling & 45 & (9) & (4) & - \\
\hline
\end{tabular}

When analyzing the behavior of Hovenia dulcis wood in conventional kiln drying for the elaborated (soft and accelerated) drying programs, it is observed that the initial moisture content of the woods was statistically equal (88 and 92\%) (Figure 2).

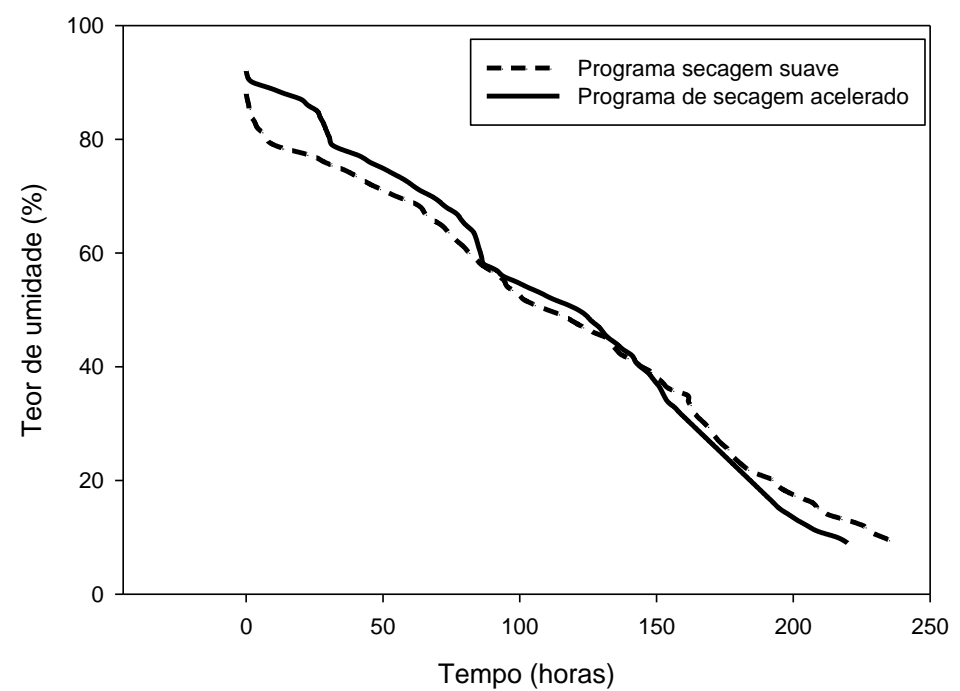

Figure 3. Moisture loss of Hovenia dulcis wood in function of drying programs assessed.

Figura 3. Perda de umidade da madeira de Hovenia dulcis em função dos programas de secagem avaliados.

The drying curves obtained were very similar, with drying times ranging from 219 hours for the accelerated program to 237 hours for the soft program, with reduction in drying time of $7.6 \%$ (Figure 3). For

FLORESTA, Curitiba, PR, v. 49, n. 1, p. 079-088, Jan / Mar. 2019

Loiola. P. L. et.al.

Electronic ISSN 1982-4688 
times of wood moisture removal in function of elaborated drying programs, it is observed that the increase in drying potential provided a reduction of $4.74 \%$ and $13.09 \%$, at times of water removal, both capillary and diffusion in wood, having the cycle of drying a $7.41 \%$ reduction, respectively (Table 7).

Table 7. Time and drying rate of Hovenia dulcis wood in conventional drying.

Tabela 7. Tempo e taxa de secagem da madeira de Hovenia dulcis na secagem convencional.

\begin{tabular}{|c|c|c|c|c|c|c|c|}
\hline \multirow{2}{*}{$\begin{array}{c}\text { Drying } \\
\text { program }\end{array}$} & \multirow{2}{*}{$\begin{array}{c}\text { Drying } \\
\text { potential }\end{array}$} & \multicolumn{3}{|c|}{$\begin{array}{l}\text { Drying time } \\
\text { (hours) }\end{array}$} & \multicolumn{3}{|c|}{$\begin{array}{c}\text { Drying rate } \\
\left(\mathbf{U} \% \text { hour }^{-1}\right)\end{array}$} \\
\hline & & $\begin{array}{l}\text { green up } \\
\text { to } 30 \%\end{array}$ & $\begin{array}{l}30 \% \text { up } \\
\text { to } 9 \%\end{array}$ & $\begin{array}{c}\text { Green } \\
\text { up to } 9\end{array}$ & $\begin{array}{l}\text { green up } \\
\text { to } 30 \%\end{array}$ & $\begin{array}{c}30 \% \\
\text { up to } 9 \%\end{array}$ & $\begin{array}{c}\text { Green } \\
\text { up to } \\
9 \%\end{array}$ \\
\hline Smooth & 1,91 & 161,58 & 75,84 & 237.42 & 0,3342 & 0,2769 & 0,3327 \\
\hline Accelerated & 2,80 & 153,92 & 65,91 & 219,83 & 0,3768 & 0,3186 & 0,3776 \\
\hline
\end{tabular}

Analyzing the rate of drying, you can observe the influence of drying potential at the speed of moisture removal. The difference in the rate of drying to the capillary water removal and water diffusion was $11.31 \%$ and $13.09 \%$, respectively, while the rate of average drying timber Hovenia dulcis had an increase of $11.89 \%$ (table 7).

\section{DISCUSSION}

\section{Yield in lumber and operational efficiency}

Murara Junior et al. (2013) claim that the quality of the log influences directly in the yield. So, the decision to select the logs with straight stems affected positively this homogeneity, causing the increase of yield in lumber. Pedro et al. (2014), evaluating the yield of two lumber species of the genus Eucalyptus (E. saligna and E. cloesiana) deployed in a portable sawmill, obtained yield values lower than those of $H$. dulcis wood ( $40.35 \%$ and $42.10 \%$, respectively). It is worth mentioning that the authors used a successive tangential cut diagram in their studies, obtaining a diametric classification of 30.0 to $34.5 \mathrm{~cm}$ and of 35.0 to $39.5 \mathrm{~cm}$ in diameter.

In a study made by Batista et al. (2015) on operational performance in a small sawmill, it was observed an averaged operating efficiency of $2.77 \mathrm{~m}^{3} /$ worker/day, a higher result than the average value found in this present study $\left(0.85 \mathrm{~m}^{3} /\right.$ worker/day). Marchesan et al. (2014), in a study on technical efficiency in sawing logs of three main tropical species, found average values between 2.25 and $2.63 \mathrm{~m}^{3} /$ worker/day, superior in relation to the findings in this study. The low technology used in the sawing of logs justifies the low efficiency of portable sawmill technique used in the study, in relation to conventional sawmills.

\section{Elaboration of the drying program}

Studies on the wood of Hovenia dulcis in Brazil are recent. However, we can inform the basic density values of studies performed by Motta et al. (2014), which reported the values of 0.65 to $0.52 \mathrm{~g} . \mathrm{cm}^{-3}$ when studying timber from Espírito Santo. The specific apparent density at $12 \%$ of moisture obtained in this study was $0.655 \mathrm{~g} . \mathrm{cm}^{-3}$, also corroborating the info described by Modes et al (2012), which evaluated the natural resistance of the woods of seven forest species and found $0.697 \mathrm{~g} . \mathrm{cm}^{-3}$ for the species Hovenia dulcis. Carvalho et al. (2015), performing tests of biodegradation of Hovenia dulcis wood in lab, obtained values of $0.67 \mathrm{~g} . \mathrm{cm}^{-3}$.

The wood of Hovenia dulcis started drastic drying at $100^{\circ} \mathrm{C}$ with an average moisture content of $57.51 \%$. Initial moisture affects significantly the drying process because the capillary water removal must occur slowly and with a certain discretion, becoming a limiting factor for drying. Initial moisture combined with the anatomical structure of the species influence the drying time, as well as the drying speed of wood (BARAÚNA et al., 2014; MONTEIRO et al., 2017).

The time taken to remove the diffusion water was 2.73 times slower than the elapsed time to remove the capillary water (Table 4), which emphasizes the difficulty of removing the hygroscopic water from the wood. The moisture loss follows an exponential trend (Figure 1), similar to that described by Susin et al. (2014), who also presented exponential models in their study.

To evaluate the behavior of wood drying rate for every physical phenomenon of drying (penetration and diffusion), it was noted the classic behavior of physical phenomena according to the type of water removed from the wood (Figure 1). In the early hours of drying, when the moisture gradient still does not occur significantly (phase 1), it follows linear trend (moisture content of 80 to $60 \%$ ). The main physical phenomenon involved in 
this stage is capillarity. Even at this stage, the surface of the wood is well above the point of fibers saturation, occurring capillary flow. This corresponds to the constant drying period, in which the rate of moisture loss is constant and the temperature of saturated wood surface remains similar to the wet bulb temperature of the stove. This drying phase is terminated when the moisture film contained in the surface of the wood does not maintain itself. Thus, the first superficial layers reach the fiber saturation point, changing the mechanism of the fluid flow, which initiates the second phase of drying (HILDBRAND, 1970).

In the second kinetic phase of drying, the wood moisture removal occurs by physical phenomena of capillarity and diffusion, being the predominant capillarity in the early stages. Hildbrand (1970) further complemented that, as the moisture content decreases, the fluid flow in this phenomenon (capillarity) occurs less expressively, being predominant the flow of fluids by diffusion. Due to fact that the fluid flow occurs by diffusion phenomenon, the drying rate is influenced by the thermodynamic conditions of the air flow and the intrinsic characteristics of the wood itself, giving that the drying rate occurs in descending order, as a parabolic function ( 55 to $25 \%$ of moisture).

The third stage of drying occurs with the drying rate still decreasing, and it is initiated when the removal of the wood moisture is processed only by diffusion forces. Heat transfer occurs by conduction in almost all its totality, and the drying speed is regulated by the intrinsic characteristics of wood (HILDBRAND, 1970).

\section{Application of the program of drying elaborated in the conventional drying}

The initial moisture content between the loads should be statistically equal so that there is no influence on the other variables analyzed (Figure 2). The initial moisture of the wood to be dried is of major importance, as it is directly related to the mass of water to be removed and, consequently, to defects caused in the process of removal of moisture, and the elapsed time for drying, which is related to the rate of wood drying.

The reduction in the drying time of about $7.6 \%$ results in increased productivity when the quality of the wood is not changed and the acceptable quality level (AQL) is served according to the specification allowed for the product to be manufactured. The drying time of about 10 days is characteristic of timber of hardwoods with medium to difficult drying difficulty.

It was expected an increase in the drying rate by withdrawing the free water to the accelerated drying program (potential of 2.80). However, it was not observed this behavior for the drying curve, which shows that the Hovenia dulcis wood presents difficulty in removal of free water, and can be considered a medium to hard wood to dry. Motta et al. (2014) considered that the Hovenia dulcis wood has small anatomical elements of very short fibers and with small cellular cavities, resulting in low permeability of wood.

\section{CONCLUSIONS}

- $\quad$ The lumber yield of Hovenia dulcis is within that specified for hardwood species. The two classes showed similar results of yield (47.30 and 48.94\%).

- Technical efficiency proved to be inferior in comparison to other studies, being justified by the low technology used in the cutting process. For the technical efficiency, the highest diametric class presented the best result $\left(0.95 \mathrm{~m}^{3} / \mathrm{op} / \mathrm{shift}\right)$.

- $\quad$ The wood of Hovenia dulcis was classified as moderately heavy due to its basic specific mass, and it can be considered difficult to dry according to the parameters found for the elaboration of the drying programs.

- In conventional stove drying, the increase in drying potential resulted in a small increase in the drying rate.

\section{REFERENCES}

AMERICAN SOCIETY FOR TESTING AND MATERIALS. ASTM D-2395: Standard Test Methods for Specific Gravity of Wood and Wood-Based Materials. Philadelphia, 2005. 8 p.

AMERICAN SOCIETY FOR TESTING AND MATERIALS. ASTM D-4442: Standard Test Methods for Direct Moisture Content Measurement of Wood and Wood-Base Materials. Philadelphia, 2005. 6 p.

BARAÚNA, E.E.P; LIMA, J.T; VIEIRA, R.S; SILVA, J.R.M; MONTEIRO, T.C Effect of anatomical and chemical structure in the permeability of 'Amapá' wood. Cerne, Lavras, v. 20, n.4, p. 529-534, 2014.

BATISTA, D. C.; SILVA, J. G. M.; ANDRADE, W.S.P.; VIDAURRE, G. B. Desempenho operacional de uma serraria de pequeno porte do município de Alegre, Espírito Santo, Brasil. Floresta, Curitiba, v. 45, p. 487-496, 2015.

FLORESTA, Curitiba, PR, v. 49, n. 1, p. 079-088, Jan / Mar. 2019

Loiola. P. L. et.al.

Electronic ISSN 1982-4688 
CARVALHO, P.E.R. Ecologia, silvicultura e usos da uva-do-japão (Hovenia dulcis Thunberg). Colombo: EMBRAPA-CNPF, 1994. 24 p. (EMBRAPA-CNPF. Circular técnica, 23).

CARVALHO, D. E; SANTINI, E. J.; GOUVEIA, F. N.; ROCHA, M. P. Resistência natural de quatro espécies florestais submetidas a ensaio com fungos apodrecedores. Floresta e Ambiente. v. 22, n. 2, p. 271 - $276,2015$.

ELEOTÉRIO, J. R.; SILVA, C.M.K. Drying programmes for marupá (Simaroubaamara ), stop stop (Jacarandacopaia) and ferrule ( Virolasurinamensis ). Floresta, Curitiba, v. 44, n.2, p. 313-322, 2014.

ELEOTÉRIO, J. R.; BAGATOLLI, T. R.; HORMBURG, K. B.; SILVA, C. M. K. Secagem drástica de madeiras de Eucalyptus e Corymbia fornece informações para a elaboração de programas de secagem. Pesquisa Florestal Brasileira, Colombo, v. 35, n. 84, p. 451-457, 2015.

GALVÃO, P. M.; JANKOWSKI, I.P. Secagem racional da madeira. São Paulo: Nobel, 1985. 111p.

HILDBRAND, Rr. Kiln drying of saw timber. Germany: R.H. Maaschinembau Gmbh, 1970. 204p.

JUÍZO, C. G. F.; LOIOLA, P. L.; MARCHESAN, R.; JOSSEFA, C. G.; CHAORA, I. J.; ROCHA, M. P.; KLITZKE, R. J. Influência da classe diamétrica no rendimento em madeira serrada de duas espécies nativas de Moçambique. Pesquisa Florestal Brasileira, v. 35, p. 293, 2015.

KLITZKE, R. J.; BATISTA, D. C. Ensaio de taxa de secagem e escore de defeitos para a predição da qualidade de secagem convencional da madeira de Eucalyptus. Scientia Forestalis. Piracicaba, v. 38, n. 85, p. 97-105, 2010 .

LOIOLA, P. L.; JUÍZO, C. G. F.; MARCHESAN, R.; KLITZKE, R. J.; ROCHA, M. P. Drying of wood from Mimosa scabrella, Eucalyptus dunnii and Tectona grandis in solar kiln, in south Brazil. Australian Journal of Basic and Applied Sciences, v. 9, p. 445-453, 2015.

MANHIÇA, A.A.; ROCHA, M.P.; TIMOFEICZYK JUNIOR, R. Eficiência operacional no desdobro de Pinus utilizando modelos de corte numa serraria de pequeno porte. Cerne, Lavras, v.19, n.2, p. 339-346, 2013.

MARCHESAN, R.; ROCHA, M. P.; SILVA, J. B.; KLITZKE, R. J. Eficiência técnica no desdobro principal de toras de três espécies tropicais. Floresta, Curitba, v. 44, n.4. p. 629-636, 2014.

MODES, K.S.; LAZAROTTO, M.; BELTRAME, R.; VIVIAN, M.A.; SANTINI, E.J.; MUNIZ, M.F.B. Resistencia natural das madeiras de sete espécies florestais ao fungo Pycnoporus sanguineus causador da podridão-branca. Cerne, Lavras, v.18, n.3, p. 407 - 411, 2012.

MONTEIRO, T.C.; LIMA, J.T.; HEIN, P.R.G.; SILVA, J.R.M.; TRUGILHO, P.F.; ANDRADE, H.B. Efeito dos elementos anatômicos da madeira na secagem das toras de Eucalyptus e Corymbia. Scientia Forestalis, Piracicaba, v. 45, n.115. p.495 - 505, 2017.

MOTTA, J.P.; OLIVEIRA, J.T.S.; BRAZ, R.L.; DUARTE, A.P.C.; ALVES, R.C. Caracterização da madeira de quatro espécies florestais. Ciência Rural, Santa Maria, v. 44, n. 12, p. 2186 - 2192, 2014.

MURARA JÚNIOR, M.I.; ROCHA, M.P.; TRUGILHO, P.F. Estimativa do rendimento em madeira serrada de Pinus para duas metodologias de desdobro. Floresta e Ambiente, v.20, n.4, p.556-563, 2013.

PEDRO, F.S.; JUÍZO, C.G.F.; ROCHA, M.P.; BILA, N.F.; UETIMANE, E. Avaliação do rendimento em madeira serrada de eucalipto para dois modelos de desdobro numa serraria portátil. Floresta e Ambiente, Seropédica, v. 21, n. 4, p.543-550, 2014.

SIMPSON, W. T. Dry kiln operator's manual. Madison: U.S. Department of Agriculture, 1991. 274p.

SUSIN, F.; SANTINI, E.; STANGERLIN, D.M.; MORAIS, W.W.C.; MELO, R.R. Taxa de secagem e qualidade da madeira serrada de Hovenia dulcis submetida a dois métodos de secagem. Floresta e Ambiente, Seropédica, v.21, n.3, p. 243 - 250, 2014.

TEREZAWA, S. Methods for easy determination of kiln drying schedule of wood. Wood industry, 20(5), 1965.

VIVIAN, M.A.; BELTRAME, R.; MODES, K.S.; SOUZA, J.T.; STANGERLIN, D.M.; GATTO, D.A.; SANTINI, E.J.; HASELEIN, C.R. Efeito de pré-tratamentos na taxa de secagem da madeira de Hovenia dulcis Thunb. Ciencia da Madeira. Pelotas, v.1, n.2, p. 32 - 43, 2010. 